\title{
Challenges for heart disease stem cell therapy
}

\author{
This article was published in the following Dove Press journal: \\ Vascular Health and Risk Management \\ 20 February 2012 \\ Number of times this article has been viewed
}

\section{Jane Hoover-Plow Yanqing Gong}

Departments of Cardiovascular Medicine and Molecular Cardiology, Joseph J Jacobs Center for Thrombosis and Vascular Biology, Cleveland Clinic Lerner Research Institute, Cleveland, $\mathrm{OH}$, USA
Correspondence: Jane Hoover-Plow Department of Molecular Cardiology, NB50, Cleveland Clinic Lerner Research Institute, 9500 Euclid Avenue, Cleveland, $\mathrm{OH} 44195$, USA

Tel +l 2164456639

Fax +I 2164458204

Email hooverj@ccf.org
Abstract: Cardiovascular diseases (CVDs) are the leading cause of death worldwide. The use of stem cells to improve recovery of the injured heart after myocardial infarction (MI) is an important emerging therapeutic strategy. However, recent reviews of clinical trials of stem cell therapy for MI and ischemic heart disease recovery report that less than half of the trials found only small improvements in cardiac function. In clinical trials, bone marrow, peripheral blood, or umbilical cord blood cells were used as the source of stem cells delivered by intracoronary infusion. Some trials administered only a stem cell mobilizing agent that recruits endogenous sources of stem cells. Important challenges to improve the effectiveness of stem cell therapy for CVD include: (1) improved identification, recruitment, and expansion of autologous stem cells; (2) identification of mobilizing and homing agents that increase recruitment; and (3) development of strategies to improve stem cell survival and engraftment of both endogenous and exogenous sources of stem cells. This review is an overview of stem cell therapy for CVD and discusses the challenges these three areas present for maximum optimization of the efficacy of stem cell therapy for heart disease, and new strategies in progress.

Keywords: mobilization, expansion, homing, survival, engraftment

\section{Introduction}

The recovery of function after a myocardial infarction (MI) is dependent on increasing blood flow and regeneration of tissue. Stem cells (SCs) can provide cellular precursors for cardiomyocyte differentiation, endothelial and supporting cells, as well as signals for activation of cells and prevention of apoptosis. The results of clinical trials have been encouraging, however either no change or only small increments in recovery were found. Recent reviews of completed clinical trials (2002-2010) for SC therapy report improvements of $10 \%$ or less in about half of the studies. ${ }^{1-4}$ In the review by George, ${ }^{1} 13$ studies of SC therapy for acute MI were described. In the eight randomized controlled studies, bone-marrow (BM) cells were administered by intracoronary injection and left ventricular ejection fraction (LVEF) measured 3-6 months following the MI. In five of the randomized controlled trials, there was only an average increase of $6 \%(3 \%-12 \%)$ in cardiac function. Mozid et $\mathrm{al}^{2}$ reported two additional studies of BM SC therapy for acute MI, ${ }^{5,6}$ and only one study showed improvement (5\%) of LVEF function. Mozid et $\mathrm{al}^{2}$ also described eight clinical trials of SC therapy for chronic ischemic heart failure. There was improvement in LVEF in three of the four studies in patients treated with BM SCs and improvement in two 
of the four studies in patients transplanted with autologous skeletal myoblasts. Wen et $\mathrm{al}^{4}$ performed a meta-analysis of eight randomized controlled trials and concluded that BM cell therapy provided only moderate $(6 \%-10 \%)$ but definite improvements in LVEF. SC therapy has the potential to provide gains not only for MI, but also for chronic ischemia and heart failure. Currently, there are 33 ongoing clinical trials described on the ClinicalTrials.gov Website ${ }^{7}$ (see Table 1). While autologous BM cells are still the major source of SCs in the ongoing studies, new SC sources are rigorously being investigated. SC therapy for cardiovascular disease (CVD) is an intensive area of research, and collective improvements in the source and number of SCs, and better mobilizing and homing agents, are needed to increase the effectiveness of this emerging therapy.

\section{Challenges for SC therapy Improved identification and expansion of autologous SCs and their role in cardiac recovery}

In the 1960 s, Till et al, ${ }^{8}$ while studying the components responsible for regenerating blood cells, defined two required properties of SCs: (1) self-renewal - the ability to go through numerous cycles of cell division while maintaining the undifferentiated state; and (2) potency - the capacity to differentiate into specialized cell types. SCs are identified by their capacity to form colonies in culture and by cell surface markers that are cell specific. The majority of clinical trials of SC therapy for heart disease have used BM cells, particularly the mononuclear cells (MNCs) (Figure 1). In the ongoing trials listed

Table I Ongoing clinical trials of stem-cell therapy for heart diseases

\begin{tabular}{|c|c|c|c|c|}
\hline Condition & Stem cells & Phase & Acronym & ClinicalTrials.gov NCTID \\
\hline Congestive heart failure & Skeletal myoblasts & II/III & MARVEL & NCT00526253 \\
\hline Old MI & Skeletal myoblasts & ॥ & PERCUTANEO & NCT00908622 \\
\hline Angina, coronary disease & Bone marrow & II & & NCT0I 214499 \\
\hline Ischemic heart disease & Bone marrow & II & & NCT00690209 \\
\hline CAD, AMI & Bone marrow & $\mathrm{I} / \mathrm{II}$ & REPAIR-ACS & NCT007II542 \\
\hline MI, ischemia & Bone marrow & $\mathrm{I} / \mathrm{II}$ & & NCT0I26733I \\
\hline AMI & Bone marrow & II/III & REGEN-AMI & NCT00765453 \\
\hline CAD & Bone marrow & II/III & & NCT00I 30377 \\
\hline Chronic ischemic heart failure & Bone marrow & II/III & REGEN-IHD & NCT00747708 \\
\hline MI & Bone marrow/AC I33 & III & & NCT0II6775I \\
\hline Congestive heart failure & Bone marrow & $\mathrm{I} / \mathrm{II}$ & & NCT0I06I580 \\
\hline $\begin{array}{l}\text { Non-ischemic dilated } \\
\text { cardiomyopathy }\end{array}$ & Bone marrow & $\mathrm{I} / \mathrm{II}$ & POSEIDON-DCM & NCT0I392625 \\
\hline Dilated cardiomyopathy & Bone marrow & II & NOGA-DCM & NCT0I350310 \\
\hline Cardiomyopathy & Bone marrow & II & REGENERATE-DCM & NCT01302I7I \\
\hline Ischemic heart failure & Bone marrow/PBC & III & ESCAPE & NCT0084I958 \\
\hline Left ventricular dysfunction & Bone marrow & II & TIME & NCT0068402I \\
\hline Left ventricular dysfunction & MSC, bone marrow & $\mathrm{I} / \mathrm{II}$ & TAC-HFT & NCT00768066 \\
\hline Ischemia, left ventricular & MSC & $\mathrm{I} / \mathrm{II}$ & MESAMI & NCT0I076920 \\
\hline \multicolumn{5}{|l|}{ dysfunction } \\
\hline MI & Mesenchymal precursors & $\mathrm{I} / \mathrm{II}$ & & NCT00555828 \\
\hline AMI, heart failure & MSC & III & ESTIMATION & NCT0I394432 \\
\hline Chronic ischemic heart disease & MSC & II & MyStromalCell & NCT0I449032 \\
\hline Congestive heart failure & MSC & $\mathrm{I} / \mathrm{II}$ & & NCT006444I0 \\
\hline Dilated cardiomyopathy & CD34+ & II & & NCT00629018 \\
\hline AMI & CDI33+ & & SELECT-AMI & NCT00529932 \\
\hline MI & CDI33+ & $\| / I I I$ & & NCT0II 87654 \\
\hline MI, CAD & CDI33+ & $\mathrm{I} / \mathrm{II}$ & PERFECT & NCT00950274 \\
\hline CAD & CDI33+ & III & & NCT0I049867 \\
\hline MI, heart failure & CDI33+ & II & IMPACT-CABG & NCT0I0336I7 \\
\hline AMI & Adipose tissue-derived & $\| / I I I$ & ADVANCE & NCT0I 216995 \\
\hline Heart failure & Cardiac progenitor & 1 & TICAP & NCT0I 273857 \\
\hline Congestive heart failure & Cardiac & 1 & ALCADIA & NCT0098I006 \\
\hline MI & Cardiosphere & I & CADUCEUS & NCT00893360 \\
\hline$C A D$, congestive heart failure & Cardiac & I & SCIPIO & NCT0047446I \\
\hline
\end{tabular}

Source: ClinicalTrials.gov Website. ${ }^{7}$

Abbreviations: AMI, acute myocardial infarction; CAD, coronary artery disease; MI, myocardial infarction; MSC, mesenchymal stem cell; PBC, peripheral-blood cell. 


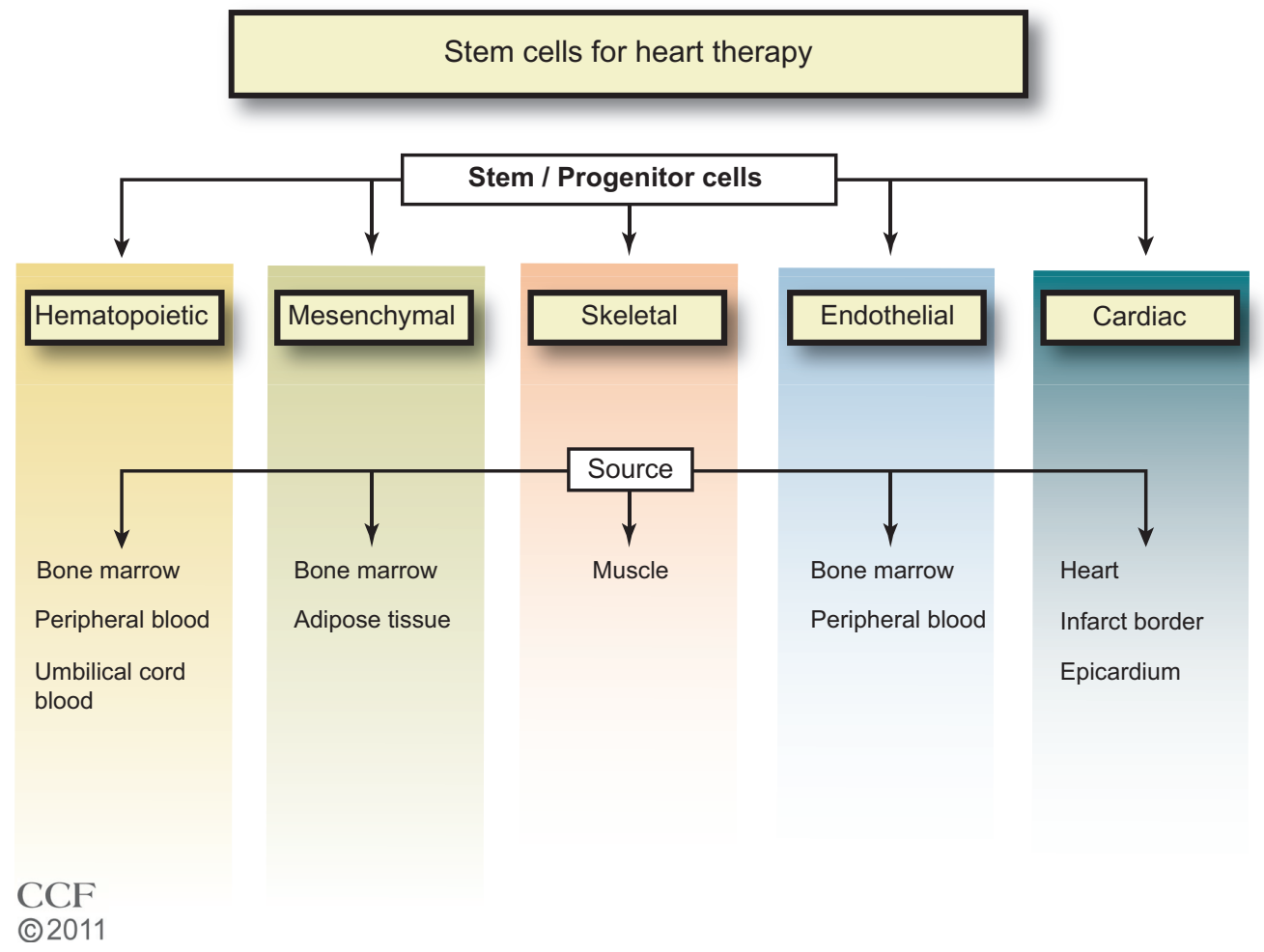

Figure I Types of stem cells in use for heart disease therapy. ${ }^{1-7}$

Reprinted with permission, Cleveland Clinic Center for Medical Art \& Photography (c) 20I I-20I2. All Rights Reserved.

in Table 1, other types of SCs are being tested, including specific BM, CD34+ or CD133+, and mesenchymal cells. One study tests adipose tissue-derived SCs, and three trials are testing cardiac progenitor/stem cells.

\section{Skeletal myoblasts}

Skeletal myoblasts isolated from muscle biopsies were the first cells used for the SC therapy for cardiac recovery. ${ }^{9}$ In a comparison of rats with chronic MI, treated with human skeletal myoblasts or BM-derived CD133+ progenitors, improvements in cardiac function were similar with the two cell types. ${ }^{10,11}$ In trials of skeletal myoblast treatment ${ }^{3}$ in patients with chronic ischemic heart failure, there were improvements in LVEF in two of four studies (SEISMIC, TOPCARD-CHD). ${ }^{3}$ While the initial evaluation in clinical studies of skeletal myoblast treatment showed there was improved function, the effect was not sustained, and the cells were not electrically integrated into the heart. ${ }^{12}$ Enthusiasm for this approach has waned. However, second-generation products are now being developed. ${ }^{9,13}$ Six trials of skeletal myoblast therapy have been discontinued, but currently there are two active trials with skeletal myoblasts (Table 1) for patients with an old MI (PERCUTANEO) or congestive heart failure (MARVEL).

\section{Hematopoietic progenitor/stem cells (HPSCs)}

In clinical trials for MI or ischemic heart disease, BM, peripheral blood (PB), or umbilical cord blood (UCB) have been used as the source of SCs. ${ }^{1,3}$ Autologous BM and PB have an advantage over UCB cells since UCB cells may be at risk for immunological rejection. However, the UCB have a high proliferation potential. ${ }^{12}$ Autologous BM cells from aging individuals may have reduced transplant efficiency, and UCB cells would be advantageous. ${ }^{14,15} \mathrm{~A}$ limitation of the PB is the low yield of SCs. BM is the major source of adult SCs and the best characterized. The BM cells have long been used in therapeutic BM replacement for blood diseases. ${ }^{16-18}$ BM SCs provide the myeloid and lymphoid lineages that give rise to blood cells. ${ }^{19}$ The cell surface markers that identify hematopoietic SCs (HSCs) for humans include: CD34+, CD59+, Thy1/CD90+, CD381o/-, c-kit/CD117+, and lin-. There are differences in mouse HSC markers; namely, CD34lo/-, Sca-1+, Thy1.1+/lo, and CD38+, but with c-kit+ and lin- as common markers. The lineage negative designation includes the absence of 13-14 cell surface markers found on mature cells. BM has been the major source of SCs for reported and ongoing clinical trials. Currently, studies are underway that isolate subsets of the 
BM cells such as CD34+, and CD133+ for use in therapy. Whether these subsets of SCs will have an advantage in heart disease recovery remains to be seen.

\section{Endothelial SCs}

Stages of lineage development of endothelial SCs and their sites of origin are less well defined than those for the hematopoietic lineage. ${ }^{20}$ The endothelial progenitor cells (EPCs) found in the PB are thought to originate in the BM from a subset of SCs or from the myeloid precursors. There is considerable controversy with regard to the identification of the EPCs. ${ }^{21}$ Some investigators have identified the EPCs as CD34+ cells and/or CD133+ cells, ${ }^{22}$ while others view these cells as HPSCs. ${ }^{23,24}$ Recently, ${ }^{25,26}$ a consensus definition of EPC markers was suggested for cross-study comparisons and with the cell surface markers CD31+, CD34 bright, and CD45, AC133, CD14, CD14a, CD235a, Live/Dead Violet negative. Of importance for identification of the EPC is the ability to become endothelial cells (ECs) in culture. While CD34+ and/or CD133+ cells in culture may become ECs, the CD34+ and/or CD133+ cells could be a mixture of subpopulations. However, the cells identified as CD34+ and/or CD133+ may be more effective in providing paracrine factors and stimulating neovascularization than the commonly used BM MNCs. Tongers et $\mathrm{al}^{27}$ recently described the results of a clinical trial for patients with refractory angina treated with intramyocardial autologous CD34+ cells, finding significant improvements in angina frequency and exercise tolerance. There is one clinical trial currently underway for treatment with CD34+ in patients with dilated cardiomyopathy, and five clinical trials underway for the treatment of MI, CAD, and heart failure with CD133+ cells. One study, NCT01187654, will compare the treatment of CD133+ cells and BM MNC in MI patients. This comparison could be informative as to whether the CD133+ cells have an advantage over the more frequently used BM MNC. Bissels et $\mathrm{al}^{28}$ found that microRNAs were expressed differentially in CD133+, CD34+, and CD133- cells involved in differentiation, prevention of apoptosis, and cytoskeletal remodeling.

\section{Mesenchymal SCs (MSCs)}

The MSCs are found in the BM and other tissues. MSCs are positive for CD44, CD73, CD90 (Thy1), and CD105, and negative for the hematopoietic markers, CD45, lineage markers, EC (CD31), and macrophage (CD11b/MAC-1). ${ }^{29}$ The MSCs have advantages over HSCs. ${ }^{27,30}$ Compared with HSCs, MSCs are more abundant, readily proliferate in culture, and are easily differentiated into different cell types, such as adipocytes, fibroblasts, osteocytes, and myoblasts. Further, studies suggest that MSCs may be more potent for cardiac repair than HPSCs. ${ }^{31}$ Although the MSCs can be differentiated into cardiomyocytes, immortalization was important and could increase the potential of tumor formation. ${ }^{15}$ In addition to $\mathrm{BM}$, adipose tissue can also be used as an abundant source of MSCs. ${ }^{32,33}$ The MSCs from UCB, adipose tissue, and BM expressed the same cell surface markers; however, there are some differences in the percentage of certain markers and colony heterogeneity. Gaebel et $\mathrm{al}^{34}$ compared treatment of MI in mice with MSCs from UCB, adipose tissue, and BM. Cells from BM, adipose tissue, and UCB CD105+ showed improvements in heart functions, decreased infarct size, and capillary density. UCB CD105 treated mice had reduced collagen deposition compared with BM and adipose tissue cells, and BM and UCB CD105 cells additionally had reduced apoptosis when compared with mice treated with adipose tissue cells. This study suggests that the function of the MSCs may be dependent on the source. Clinical trials with $\mathrm{MSCs}^{35-37}$ are promising, and currently there are 19 clinical trials underway. ${ }^{7,38}$ In a recent randomized, double blind, placebo-controlled study ${ }^{37}$ with MSC therapy after acute MI; there was improvement in the global assessment of cardiac function at 6 months in $45 \%$ of the patients.

\section{Cardiac progenitor cells (CPCs)}

Although it had been believed for a long time that cardiac myocytes were terminally differentiated, dividing myocytes found in the heart implied that there are resident or noncardiac cardiomyocyte progenitor cells. ${ }^{39}$ There have been intensive efforts to identify the cardiomyocyte stem and progenitor cells in the last 10 years. ${ }^{39}$ Purified cardiomyocytes isolated from rodent hearts dedifferentiate and divide, expressing SC markers such as c-kit, Sca-1, Isl1, and Abcg $2 .{ }^{40-45}$ CPCs have been isolated from human myocardial biopsies. ${ }^{46,47}$ These same cells can organize into spheres and re-differentiate into myocytes and ECs. ${ }^{48}$ Yamada et $\mathrm{al}^{49,50}$ suggested that $\mathrm{CD} 133^{+}$ cells from brown adipose tissue were highly effective in differentiation into cardiomyocytes compared with HPSCs, and that mouse BAT CD133+ cells efficiently induced BM SCs into cardiomyocytes (CD45- CD31- CD105+) differentiation. There are four ongoing clinical studies to test autologous CPCs (Table 1); one study (ALCADIA) will use cardiacderived SCs to treat ischemic cardiomyopathy, and two studies will take advantage of the cardiosphere-derived stem/ progenitor cells (derived from cell outgrowth of autologous cardiac biopsy) for patients with a recent MI (CADUCEUS) or heart failure (TICAP). In the SCIPIO trial, patients with 
ischemic cardiomyopathy are treated with c-kit+lin- CPCs derived from the right atrial appendage, and initial results from 16 patients report that LVEF increased and infarct size decreased. ${ }^{51}$

\section{Adipose tissue-derived SCs (ASCs)}

Cells isolated from adipose tissue can be separated by centrifugation into adipocytes and stromal vascular cells. The stromal vascular fraction may contain preadipocytes, pericytes and EPCs, adult multipotent MSCs, circulating blood cells, fibroblasts, ECs, smooth-muscle cells, and immune cells. This stromal vascular fraction may differentiate into a number of cell lineages, including the adipocytes, cartilage, bone skeletal muscle, neuronal cells, ECs, cardiomyocytes, and smooth-muscle cells. ${ }^{52,53} \mathrm{ASCs}$ are defined as CD44 and CD105 positive, and Cd11b, CD34, and CD45 negative cells. Although there is disagreement regarding the capacity of ASCs to differentiate into ECs, freshly isolated human ASCs also consist of EPCs (CD11b, CD34, and CD45 positive cells) and when cultured they have a cobblestone appearance and take up acetylated low-density lipoprotein. Bai et $\mathrm{al}^{54}$ found that human freshly isolated adipocytes or cultured adipose tissue-derived cells underwent cardiomyogenesis through a fusion-independent pathway. Takahashi et a $\mathrm{l}^{55}$ reported that in rat femoral artery injury, ASCs did not differentiate into ECs, but were able to inhibit neointimal formation by the secretion of paracrine factors. There is one ongoing clinical trial (NCT01216995) testing adipose tissue-derived cells in patients after an acute MI.

\section{Induced pluripotent stem (iPS) cells}

Another potential source of SCs is iPS cells. ${ }^{56}$ This source relies on in vitro de-differentiation of adult cells to embryonic-like SCs and then reprogramming using specific culture conditions to induce cardiac lineage cells including cardiomyocytes, smooth-muscle cells, and ECs. Adult cells most commonly used for iPS cells are fibroblasts and may be derived from a variety of tissues such as dermal, liver, stomach, pancreas, and neural and hematopoietic cells. Endogenous non-BM SC and iPS cells have been characterized in animal models and some have been identified in adult humans. Defining these cells and their requirements for proliferation and mobilization will provide additional options for enhanced efficacy of SC therapy.

\section{Embryonic SCs (ESCs)}

The ESCs are the ideal SCs, due to the fact that cultures of embryonic cells when stimulated can develop into $>200$ adult cell types. ${ }^{38,57,58}$ Current efforts focus on establishing the conditions for directed differentiation of cells by altering the chemical composition of the culture medium, altering the culture surface, or inserting genes. ${ }^{58} \mathrm{~A}$ major challenge is the potential of uncontrolled differentiation when injected directly into an animal, and the potential for tumor formation. The promise of ESCs is to genetically modify lethal debilitating chronic disease. There are currently four clinical trials in progress of human ESCs for spinal cord injury and macular degeneration, but unfortunately none for cardiac disease. ${ }^{38}$

\section{Expansion of SCs}

A critical step for improved SC therapy is the expansion of accessible SCs (Figure 2). The homing of cells to injured tissues is very inefficient, and increasing the number of cells that are available for treatment would be beneficial. Autologous BM cells, adipose tissue, myocardial, and UCB are cultured ex vivo to increase the number of cells. Culturing the tissue also allows selection of specific cells. The ESCs and iPS cells require additional steps prior to expansion of a preparation. The iPS cells require de-differentiation as an initial step and then both iPS cells and ESCs are induced to differentiate prior to expansion. SCs in culture form colonies, and proliferation without differentiation requires a specific sequence and timing of the availability of growth factors and cytokines..$^{59-66}$ In addition, these cells must maintain their pluripotency. Cells need to be free of feeder-cells, serum proteins, and microbial agents. Large-scale expansion with maintenance of pluripotency and transplant safety is required. ${ }^{58,67}$ Currently, effective cell culture proliferation is limited, ${ }^{61}$ and further studies are needed to understand the requirements for expansion. New approaches are being investigated including the use of nanofibers with growth factors, mesenchymal stromal cells in cultures of HSCs, and genetic manipulation of UCB HSCs ${ }^{68-72}$ To improve SC therapy, improved methods of SC ex vivo expansion are required.

\section{Identify mobilizing agents with improved effectiveness SC niches}

Intensive studies are underway to identify new sources of stem and progenitor cells for therapy. In addition to BM, $\mathrm{SC}$ niches have been identified (Figure 3) in heart. The SC niches are defined as a microenvironment with one or more SC that regulates self-renewal and progeny in vivo. ${ }^{73,74}$ Selfrenewal occurs in all tissues and in addition to BM, niches of SCs have been identified in heart, arteries, veins, gonads, intestine, epidermal tissue, and neural tissue. ${ }^{73,75-77}$ The 


\section{EXPANSION OF STEM CELLS}

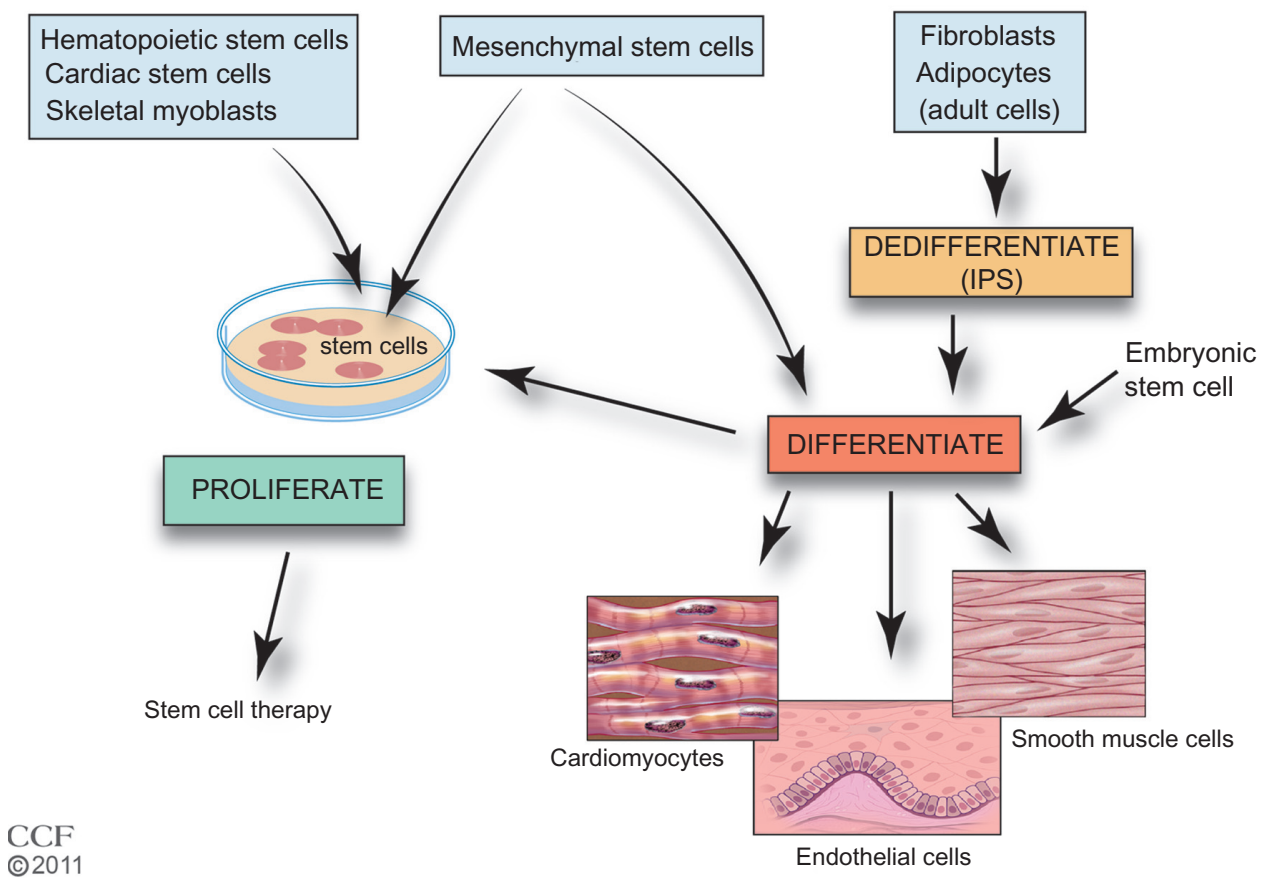

Figure 2 Expansion of stem cells.

Reprinted with permission, Cleveland Clinic Center for Medical Art \& Photography @ 20II-20I2. All Rights Reserved.

Notes: Currently, increased numbers of autologous hematopoietic, mesenchymal, cardiac, endothelial, and skeletal stem cells can be generated by expansion in culture with proliferation specific conditions. Adult cells such as fibroblasts or adipocytes may be dedifferentiated in culture to stem cells (iPS cells). MSCs, iPS cells, and ESCs can be induced to differentiate and proliferate in cell culture. Use of differentiated MSCs, iPS cells, and ESCs is in preclinical development.

Abbreviations: ESC, embryonic stem cell; iPS, induced pluripotent stem; MSC, mesenchymal stem cell.

non-BM SCs were initially defined by immunofluorescence in tissue, but given the number of markers needed, this became untenable, and isolation and identification of SCs by flow cytometry using multiple markers simultaneously has made it possible to isolate and investigate the function of these cells. Recently, lineage mapping has been utilized to locate niches in animal models by genetically labeling SC markers and identifying their location in adult tissue. ${ }^{78,79}$ An example of lineage mapping is the recent study of Tamura et $\mathrm{al}^{78}$ of neural crest-derived SCs found in the heart that migrate and differentiate into cardiomyocytes after MI. The lineage mapping has been utilized for locating SC niches in a variety of developing organisms. ${ }^{79}$ The number of quiescent SCs is small, and better detection methods are necessary. Further, identifying the regulation and recruitment of these endogenous SCs in adults is critical.

\section{Mobilization of BM SCs}

In the BM, SCs reside in an endosteal niche along with stromal cells, mesenchymal cells, and ECs. The SCs are retained in the BM with high concentrations of stromal-derived factor (SDF)-1, the major chemoattractant for SCs. The SDF-1 SC receptor, CXCR4, is found in low concentrations. Stimulation with cytokines or growth factors may interrupt ligand/ receptor balance. With a decrease in SDF-1 and an increase in CXCR4 expression, a signaling gradient with the PB allows the egress of the SCs from the BM (Figure 4). Granulocyte colony-stimulating factor (G-CSF) is widely used clinically for SC mobilization and sometimes in conjunction with other factors ${ }^{57,80}$ including granulocyte-macrophage colonystimulating factor, stem cell factor, fms-like tyrosine kinase (Flt)-3 ligand, and interleukin-1, -3, -6, -7, -8, -11, and -12 (Figure 3). AMD3100, an inhibitor that blocks SDF-1 binding to CXCR4; CTCE-0021, a CXCR4 agonist; recombinant human growth hormone, a pleiotrophic cytokine; parathyroid hormone; pegfilgrastim, pegylated G-CSF with a prolonged half-life, and thrombopoietin, a cytokine that regulates megakaryocytopoiesis, are also being investigated. ${ }^{80}$

In addition to cytokines and growth factors, proteases such as neutrophil elastase, cathespin G, plasmin, and matrix metalloproteinase (MMP)-9 have been implicated in BM SC mobilization. ${ }^{81-86}$ After G-CSF treatment, these proteases increase in BM as well as in plasma; however, studies ${ }^{83}$ in mice deficient in neutrophil elastase or cathespin G suggest 


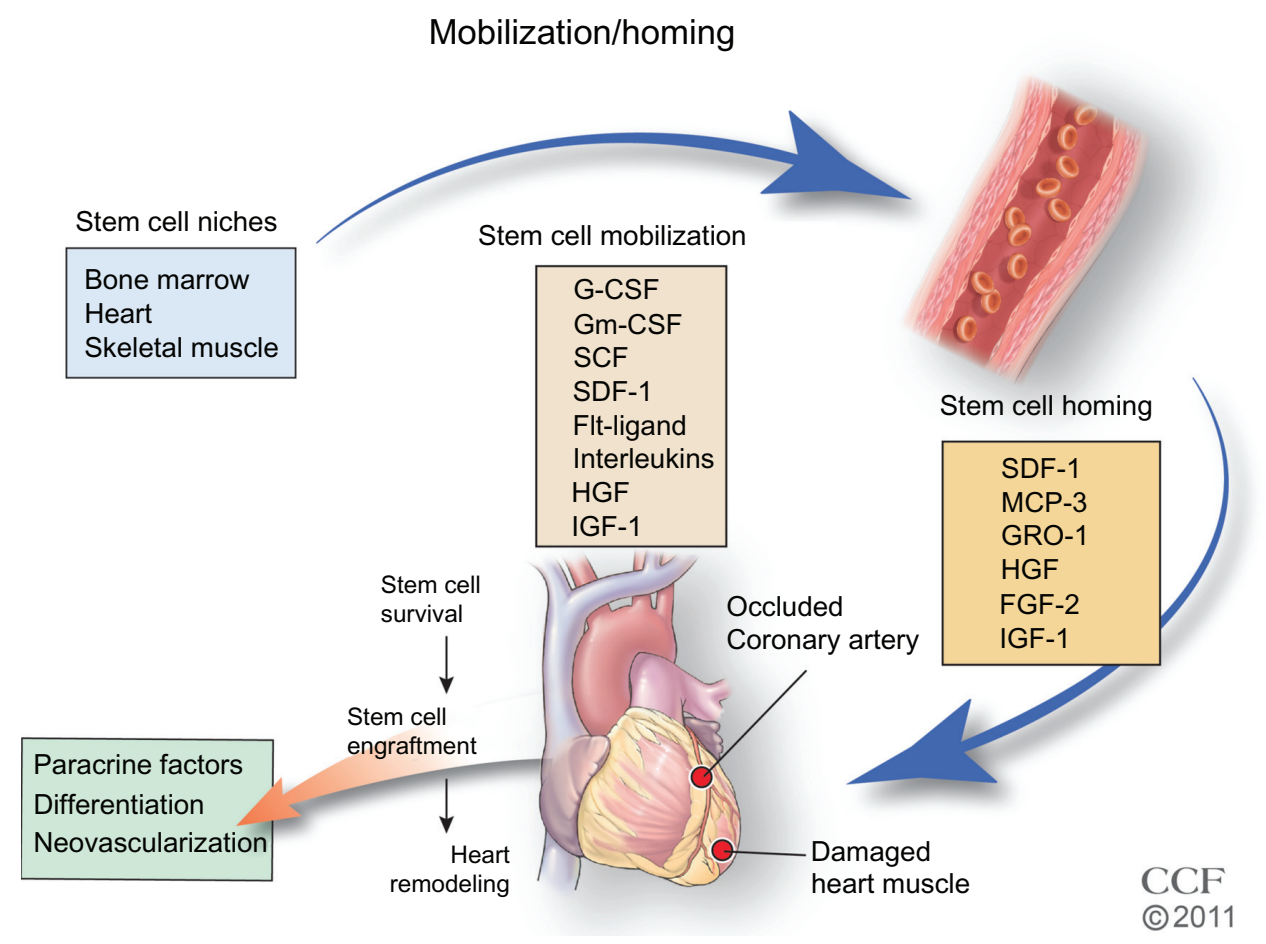

Figure 3 Stem cell mobilization and homing. Growth factors and cytokines stimulate the mobilization of the stem cells from their niche to injured tissue. Reprinted with permission, Cleveland Clinic Center for Medical Art \& Photography (C 20II-20I2. All Rights Reserved.

Notes: FIt-ligand is a growth factor; interleukins refer to interleukin-I, -3, -6, -7, -8, - II, and - I2 cytokines; homing factors MCP-3, GRO-I, HGF, FGF-2, and IGF-I are produced in the heart and promote endogenous and exogenous stem cells homing to the injured tissue; survival and implantation of stem cells in the tissue may result in differentiation, secretion of paracrine factors, and/or stimulation of angiogenesis to restore blood flow and remodel tissue.

Abbreviations: G-CSF, granulocyte colony-stimulating factor; Gm-CSF, granulocyte-macrophage colony-stimulating factor; SCF, stem cell factor/c-kit ligand; SDF-I, stromal cell-derived factor I; MCP-3, monocyte chemotactic protein-3; GRO-I, growth regulated oncogene I; HGF, hepatic growth factor; FGF-2, fibroblast growth factor; IGF-I, insulin-like growth factor.

these two proteases are not required for HPSC mobilization. The results of studies ${ }^{81,83,87,88}$ in MMP-9 deficient mice are not consistent. While some studies ${ }^{83,88}$ report MMP-9 is not required, other studies ${ }^{81,86,87}$ suggest MMP-9 plays an important role. These differences may be due to the differences in genetic background of the mice and to differences in the dose of the mobilizing agent. In a recent study, ${ }^{86}$ the authors of this present paper report that plasmin/MMP-9 is a major proteolytic pathway required for $\mathrm{SC}$ mobilization from BM (Figure 5). Plasmin activation of MMP-9 regulates the SDF-1/CXCR4 signaling. In addition, plasmin also promotes direct degradation of the ECM during SC mobilization. ${ }^{85}$ G-CSF induced HSC MMP-9 degrades BM SDF-1. ${ }^{83,89,90}$ The increase in the number of SC mobilized with G-CSF treatment may not be sufficient for the cardiac remodeling after MI, and some patients are resistant to G-CSF. ${ }^{91-93}$ AMD3100, an inhibitor of CXCR4, is a promising HSC mobilizer under clinical investigation. Studies report mild and reversible side effects ${ }^{94-96}$ and that it works synergistically with G-CSF to increase CD34+ cells and total white blood count. ${ }^{94,96-98}$ However, Dai et al recently reported that chronic AMD100 exacerbates cardiac dysfunction after $\mathrm{MI}$ in mice. ${ }^{99}$

\section{Mobilization of CPCs}

A number of cardiomyocyte progenitor pools have been identified $^{76}$ that have common and unique markers, including: side population (SP) CPCs; c-kit+ CPCs; Sca-1+ CPCs; cardiospheres and cardiosphere-derived cells; stage specificembryonic antigen-1+ (SSEA-1 $\left.{ }^{+}\right)$CPCs; LIM-homeodomain transcription factor+ (Islet-1+) CPCs; and epicardium-derived cells. The CPCs demonstrate greater proliferation potential in the infarct border compared with the necrotic core. These cells have the potential to differentiate into cardiomyocytes, smooth-muscle cells, and ECs, but the stimulatory factors for differentiation vary. The SP CPCs ${ }^{100,101}$ can be stimulated by SDF-1 and are both c-kit and Sca-1 positive, but are also positive for the ATP-binding cassette transporter (ABCG2). The cardiac SP cells are a mixture of subpopulations, and proof that these cells are SC is not definitive. The c-kit marker was used to identify and isolate HSCs, but their ability to differentiate into cardiomyocytes is controversial. ${ }^{102,103}$ Cells positive for c-kit isolated from human and rodent tissue express specific cardiac transcription factors, GATA4, GATA5, MEF2C, and Kkx2, and when cultured express mature cardiomyocyte markers, cardiac actinin, cardiac myosin, desmin, and connexin $43 .{ }^{45,104}$ 


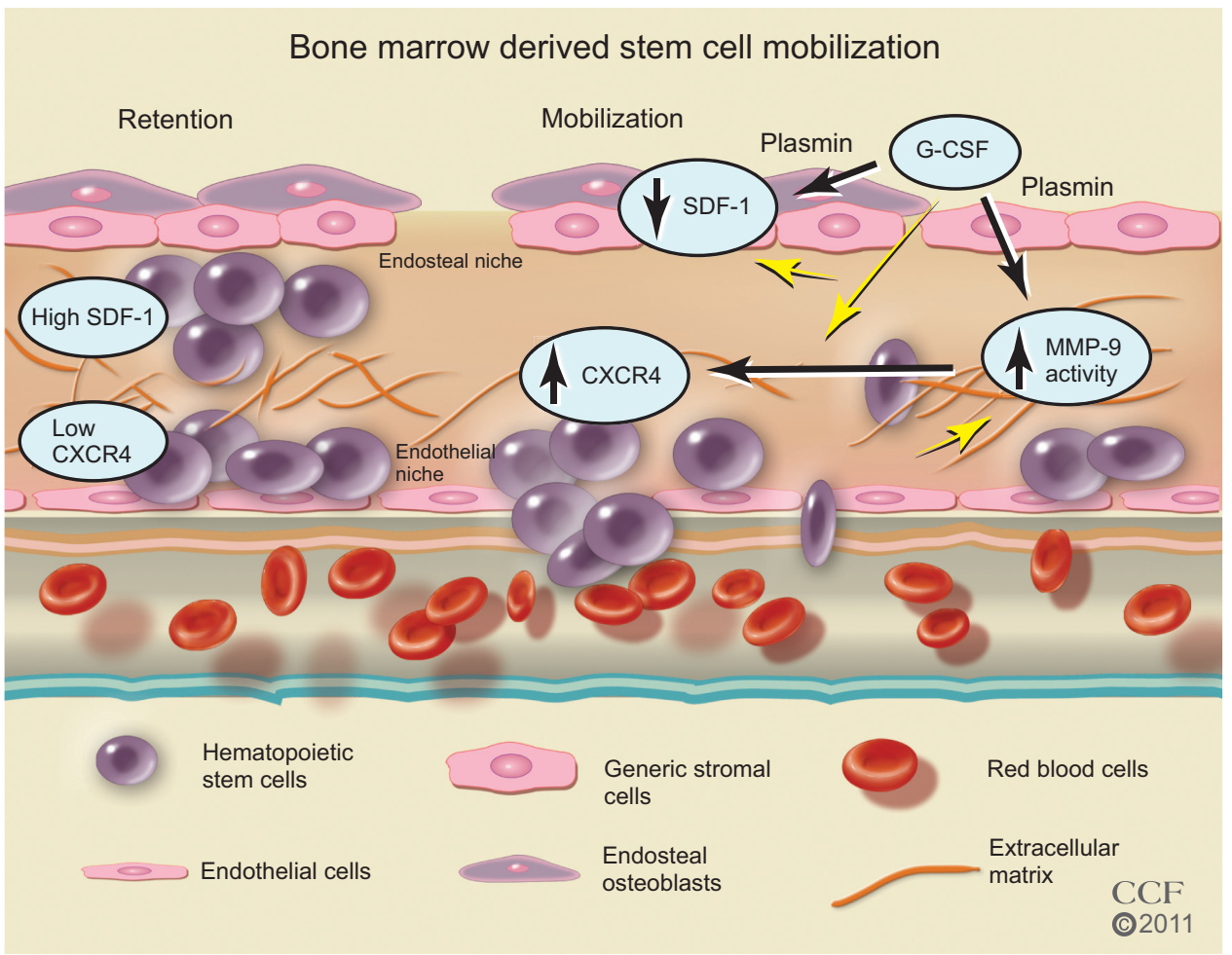

Figure 4 Bone marrow-derived stem cell mobilization. Bone marrow stem cells may be mobilized by reducing the ligand SDF-I and increasing the stem cell receptor CXCR4 to create a chemotatic gradient with the peripheral blood. G-CSF treatment increases MMP-9 to regulate changes in SDF-I/CXCR4 pathway, which is dependent on plasmin activation of MMP-9.

Reprinted with permission, Cleveland Clinic Center for Medical Art \& Photography @ 201 I-20I2. All Rights Reserved.

Abbreviations: CXCR4, C-X-C receptor 4; G-CSF, granulocyte colony-stimulating factor; MMP-9, matrix metalloproteinase-9; SDF-I, stromal-derived factor-I.

The CPCs may be stimulated by insulin-like growth factor-1 (IGF-1); hepatic growth factor (HGF) high-mobility group box protein-1 (HMGB1), a chromatin-binding protein secreted by necrotic cells, and SDF-1. ${ }^{105}$ The CPCs possess growth factor receptors and when activated increase proliferation, migration, and differentiation. Tamoxifen-treated double-transgenic mice ${ }^{48}$ expressed dedifferentiated cardiomyocytes that expressed CPC markers and $\sim 2 / 3$ expressed c-kit. Studies in zebrafish and mammalian development suggest the potential of the epicardium-derived cells, the epithelial cells in the outermost layer of the heart, to develop into cardiomyocytes in vivo. ${ }^{106}$ Smart et $\mathrm{al}^{107}$ reported that in mouse heart, thymosin $\beta 4$ can release the quiescent EPDCs. Development of small molecules to release the cells is underway. ${ }^{106}$ Isl1 + CPCs are prominent during development, and in the postnatal rat, mouse, and human myocardium, Is11+, c-kit-, Sca-1-, and CD31- cells have been defined as cardioblasts. Both iPS cells and ESCs give rise to this lineage in vivo. The Isl-1+ cells are rare in the myocardium and the possibility of endogenously recruiting or in vitro expansion appears to be limited. The SSEA- $1+\mathrm{CPCs}^{108}$ give rise to myocardial and endocardial cells during development in the neonatal and adult rat heart, but can progress to more committed c-kit+, Sca-1, and abcg2+ cells. When transplanted into rat heart, improved regeneration of infarcted myocardium results. Sca-1+ CD31+ cells are found in the heart as small interstitial cells that lack the HSC lineage markers of c-kit, Flt1, Flk-1, CD45, and CD34. ${ }^{41}$ Using transgenic mice, cardiac Sca-1+ cells were found to play a role in the regulation the signaling required for efficient myocardial regeneration. ${ }^{42,109}$ Studies with ESCs and their requirements for cardiomyocyte differentiation may shed light on the factors that induce differentiation and proliferation of the endogenous CPCs. ${ }^{110} \mathrm{~A}$ better understanding of SC mobilization from cardiogenic niches may lead to more effective agents for not only recruiting cells for ex vivo expansion, but to mobilize endogenous sources.

\section{Strategies for improving SC homing, survival, and engraftment in the injured heart SC delivery}

Available routes of SC delivery include intravenous, intracoronary, epicardial, endocardial, and coronary sinus injection. ${ }^{2,111}$ While the intravenous injection of SCs is the least invasive 


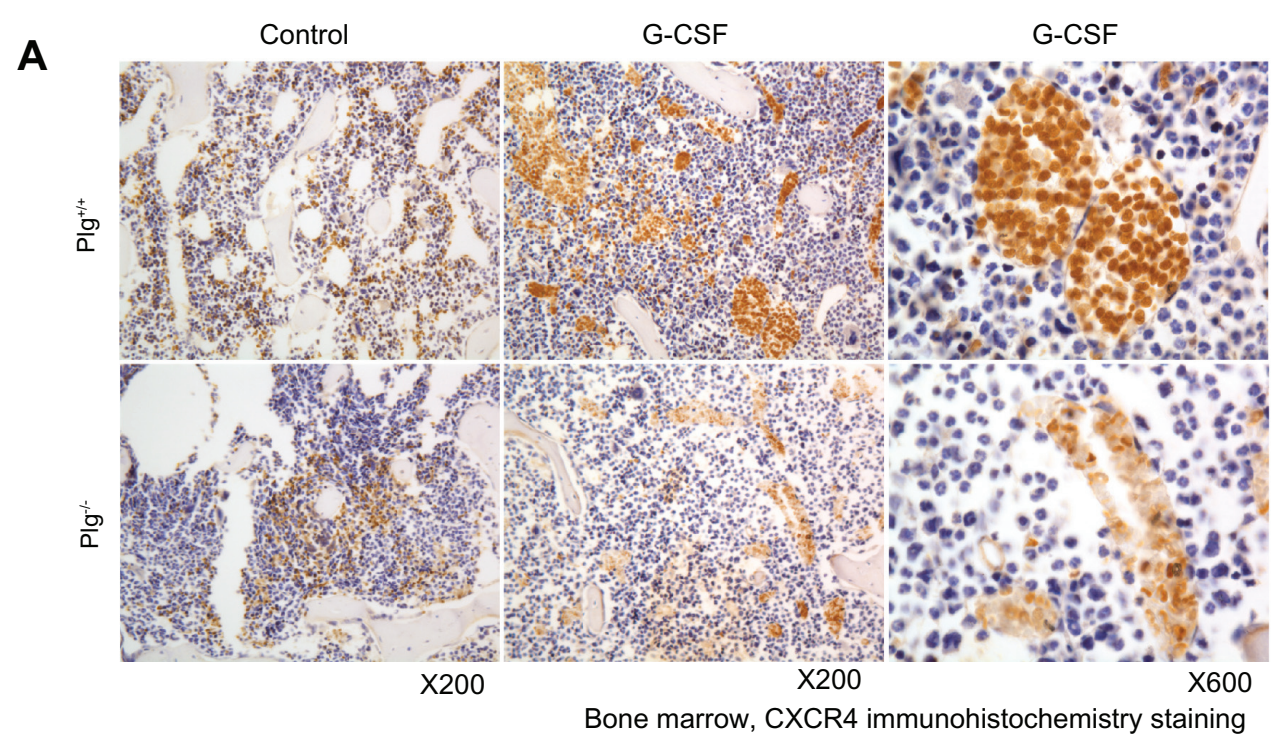

B

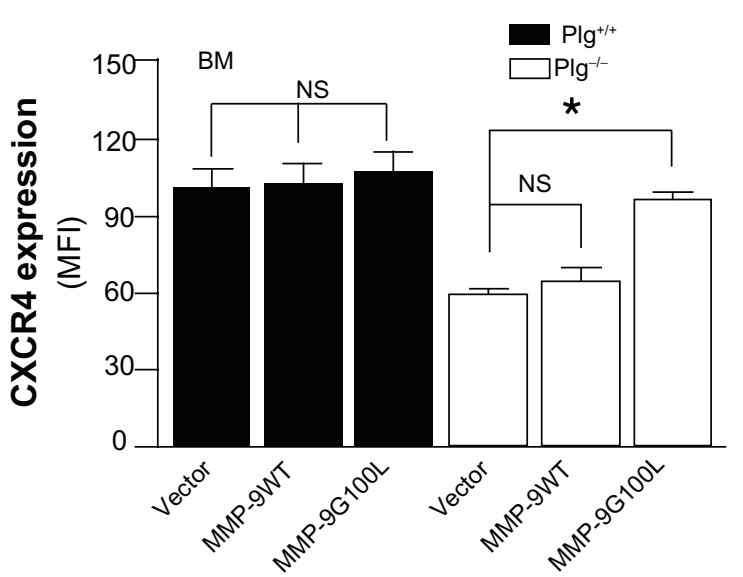

Figure 5 Plasminogen regulates CXCR4 after G-CSF stimulation. (A) CXCR4 immunostaining of bone marrow from Plg $+/+$ and Plg-/- mice treated with saline (control) or G-CSF. CXCR4 expressing cells (brown color) increased two fold after G-CSF treatment in Plg+/+ mice, but CXCR4 did not change in Plg-/- mice. (B) Lentivirus expression of act MMP-9 in Plg-1- restored CXCR4 expression. Plasminogen activation of MMP-9 is required for CXCR4 expression after G-CSF treatment.

Note: Reproduced with permission from Gong Y, Fan Y, Hoover-Plow J. Plasminogen regulates stromal cell-derived factor-I/CXCR4-mediated hematopoietic stem cell mobilization by activation of matrix metalloproteinase-9. Arterioscler Thromb Vasc Biol. 20I I;3 I (9):2035-2043.

Abbreviations: CXCR4, C-X-C receptor 4; G-CSF, granulocyte colony-stimulating factor; MFI, mean fluorescence intensity; MMP-9, matrix metalloproteinase-9; PIg, plasminogen.

method of delivery, retention of cells in the lungs is problematic. After an MI, intracoronary injection through a catheter is the preferred method of delivery. The epicardial and transendocardial are more invasive, but the most reliable. The transendocardial administration uses a percutaneous catheter-based approach. The coronary sinus delivery provides access to the infarcted and ischemic tissue, but may not be available to all patients. In the clinical trials, SCs were delivered by either bolus or multiple intracoronary injections, but only a small percentage reached the heart. ${ }^{1,112}$ At least $90 \%$ of injected cells die by apoptosis. Alternative methods of delivery are being investigated, such as use of biodegradable scaffold-based engineered tissue. ${ }^{113,114}$ An advantage is the variable size, but problematic issues are thickness of the patch and toxicity of the degraded material. Only limited improvement in cardiac function has been noted. A recent study ${ }^{115}$ tested sheets of cardiomyocytes progenitor cell and reported an increase in cardiogenesis and improved function. The development of safe and more effective materials for use in SC delivery is necessary.

\section{Homing}

Homing is the migration of SCs from endogenous and exogenous sources through the blood or tissue to a destination where they 
differentiate and replace or repair injured tissue. After an MI, expression of several factors has been observed, including transient increases in cardiac cytokines, SDF-1, MCP-3, GRO-1, that are chemo-attractants for SCs. ${ }^{116-123}$ After acute MI, the expression of these factors leads to SC homing to the infarcted tissue. However, many of the homing factors are expressed for only a short period of time after MI. SDF-1, the most studied homing factor, is expressed by the injured cardiac tissue for less than 1 week $^{123}$ and MCP-3 for less than 10 days after MI. ${ }^{124}$ In preclinical studies, genetic engineering of these factors into delivered SCs is effective in increasing SC homing. ${ }^{123,125}$ For example, the delivery of SDF-1 to the myocardium, either through cell-based gene therapy, ${ }^{123,126}$ gene transfer, ${ }^{127}$ or proteinenhanced $^{128}$ homing of SCs, results in revascularization and improvement in cardiac function. Furthermore, overexpressing SDF-1 receptor CXCR4 in SCs leads to greater homing of SCs and improved left ventricular function when the cells were delivered within 24 hours of MI. ${ }^{129-131}$ Studies in animals show that engineering cells to induce the expression of SC homing factors or their receptors in myocardial tissue can promote $\mathrm{SC}$ homing from BM to the injured myocardium; however, these have not to date been tested in humans. ${ }^{132}$

\section{Survival/engraftment}

Survival and engraftment of SCs is perhaps the most important challenge for SC therapy, and the factors necessary for effective survival and engraftment are not necessarily the same as those required for homing. After an MI, there is an enormous loss of cardiomyocytes and supporting cells that need to be replaced. The environmental signals that may guide SCs to the cardiomyocyte lineage or to the secretion of paracrine factors may be absent in the infarcted tissue, and SCs may provide these signals. Many studies have focused on strategies to optimize SC migration through injured myocardial tissue. Proteases, adhesion molecules, and integrins are important in regulating SC migration through injured myocardial tissue and modulation of the connective tissue microenvironment to improve SC engraftment. ${ }^{133-136}$

Several proteases have been identified to have significant effects on SC mobilization or SC migration and engraftment in cardiac tissue. SDF-1 and other factors induce the secretion of matrix metalloproteinase MMP-2 and MMP-9. ${ }^{137-139}$ Of significant interest, proteolytic enzymes, including neutrophil elastase, cathepsin G, and MMP-2/9, also negatively regulate cell migration by cleaving the $\mathrm{N}$-terminal region of SDF-1 or cleaving CXCR4. ${ }^{90,139-142}$ Those proteolytic enzymes are involved in spatial temporal changes in the locomotion machinery of SCs, thus mediating SC recruitment and engraftment.

Integrins are also key factors for adhesion, rolling and transmigration of SCs across the endothelium. The HSCs express several adhesion molecules including multiple integrins. In particular, a dominant role for the $\alpha 4 \beta 1$ integrin very-late antigen [VLA]-4 interaction with vascular cell adhesion molecule (VCAM)-1 has been suggested by studies in which exposure to blocking antibodies to VLA-4 or VCAM-1 significantly reduced the engraftment of transplanted HSCs. ${ }^{143-145}$ CD18 expression by the EPCs is necessary for its interaction with EC surface ICAM-1, and a CD18 neutralizing antibody significantly inhibits SC engraftment after acute MI. ${ }^{146}$ These studies suggest the potential targets for the genetic enhancement of SC recruitment and engraftment.

Several other strategies have been proposed: identifying natural mediators; pre-translational directed differentiation of SCs to cardiomyocytes; activation of growth factors (FGF-2, IGF-1a) ${ }^{132}$ and antiapoptotic factors (p-Akt, SDF-1, BCl-1, and PDGF); and genetically engineered SCs. ${ }^{125,132}$ The challenge to improve survival in SC therapy is to identify effective ways to increase the number of cells that reach and survive in the injured heart area.

\section{Assessment of SC therapy}

The goals of SC therapy are to: replace lost cardiomyocytes; increase ECs to improve blood flow; provide paracrine cytokines and growth factors; and improve measurable cardiac function, including an increase in LVEF; decrease left ventricular end-diastolic diameter; increase myocardial perfusion; and importantly increase exercise capacity. In clinical trials, methods to measure cardiac function include echocardiography, single photon emission computed tomography, and magnetic resonance imaging (MRI).,3,37,147-149 These methods are well established, but more sensitive methods are necessary to evaluate SC homing and engraftment. Techniques to evaluate the timing and specific role of narrow populations of cells, such as MRI ${ }^{150-152}$ and SC labeling with genetic ${ }^{153,154}$ and immunofluorescence detectable tags ${ }^{155}$ are being investigated in animal models. The lineage/fate mapping ${ }^{110,156-158}$ has proved to be an informative tool, and further studies in animal models and ex vivo SC labeling of cells for therapy will continue to be valuable.

\section{Conclusion}

SC therapy is an exciting and dynamic area of research with the potential to improve recovery of CVD, the leading cause of 
death. While animal models clearly show benefits of SC therapy to improve cardiac function after $\mathrm{MI}$ and ischemic heart failure, clinical trials have been disappointing. However, the results of clinical trials are promising. Better methods are needed to improve the isolation and identification of SCs, increase ex vivo expansion of SCs, and increase delivery effectiveness. A clearer understanding of mobilization and homing of SCs is needed to identify new and more effective agents. Delineating the function of specific SCs in remodeling injured tissue and how resident cardiac SCs may be enhanced is needed to improve SC engraftment and survival.

\section{Acknowledgments}

This study was funded by grants from American Heart Association (AHA0625331B and 09BGIA2050157) and the National Institutes of Health, National Heart, Lung, and Blood Institute (R01HL078701). The authors thank Beth Halasz, CMI, for the artwork for the figures.

\section{Disclosure}

The authors report no conflicts of interest in this work.

\section{References}

1. George JC. Stem cell therapy in acute myocardial infarction: a review of clinical trials. Trans Res. 2010;155(1):10-19.

2. Mozid AM, Arnous S, Sammut EC, Mathur A. Stem cell therapy for heart diseases. Br Med Bull. 2011;98:143-159.

3. Sanz-Ruiz R, Gutierrez Ibanes E, Arranz AV, Fernandez Santos ME, Fernandez PL, Fernandez-Aviles F. Phases I-III clinical trials using adult stem cells. Stem Cells Int. 2010;2010:579142.

4. Wen Y, Meng L, Xie J, Ouyang J. Direct autologous bone marrow-derived stem cell transplantation for ischemic heart disease: a meta-analysis. Expert Opin Biol Ther. 2011;11(5):559-567.

5. Hirsch A, Nijveldt R, van der Vleuten PA, et al. Intracoronary infusion of mononuclear cells from bone marrow or peripheral blood compared with standard therapy in patients after acute myocardial infarction treated by primary percutaneous coronary intervention: results of the randomized controlled HEBE trial. Eur Heart J. 2011;32(14):1736-1747.

6. Huikuri HV, Kervinen K, Niemela M, et al. Effects of intracoronary injection of mononuclear bone marrow cells on left ventricular function, arrhythmia risk profile, and restenosis after thrombolytic therapy of acute myocardial infarction. Eur Heart J. 2008;29(22):2723-2732.

7. ClinicalTrials.gov [homepage on the Internet]. Available from: http:// www.ClinicalTrials.gov. Accessed January 2, 2012.

8. Till JE, McCulloch EA, Siminovitch L. A stochastic model of stem cell proliferation, based on the growth of spleen colony-forming cells. Proc Natl Acad Sci U S A. 1964;51:29-36.

9. Menasche P. Towards the second generation of skeletal myoblasts? Cardiovasc Res. 2008;79(3):355-356.

10. Agbulut O, Vandervelde S, Al Attar N, et al. Comparison of human skeletal myoblasts and bone marrow-derived CD133+ progenitors for the repair of infarcted myocardium. $J$ Am Coll Cardiol. 2004;44(2):458-463

11. Taylor DA, Atkins BZ, Hungspreugs P, et al. Regenerating functional myocardium: improved performance after skeletal myoblast transplantation. Nat Med. 1998;4(8):929-933.
12. Gersh BJ, Simari RD, Behfar A, Terzic CM, Terzic A. Cardiac cell repair therapy: a clinical perspective. Mayo Clin Proc. 2009;84(10): 876-892.

13. Haider H, Lei Y, Ashraf M. MyoCell, a cell-based, autologous skeletal myoblast therapy for the treatment of cardiovascular diseases. Curr Opin Mol Ther. 2008;10(6):611-621.

14. Finney MR, Greco NJ, Haynesworth SE, et al. Direct comparison of umbilical cord blood versus bone marrow-derived endothelial precursor cells in mediating neovascularization in response to vascular ischemia. Biol Blood Marrow Transplant. 2006;12(5):585-593.

15. Agarwal U, Ghalayini W, Dong F, et al. Role of cardiac myocyte CXCR4 expression in development and left ventricular remodeling after acute myocardial infarction. Circ Res. 2010;107(5):667-676.

16. Feldman EJ, Gergis U. Management of refractory acute myeloid leukemia: re-induction therapy or straight to transplantation? Curr Hematol Malig Rep. 2011. [Epub ahead of print].

17. Stone RM, O'Donnell MR, Sekeres MA. Acute myeloid leukemia. Hematology Am Soc Hematol Educ Program. 2004:98-117.

18. Lodi D, Iannitti T, Palmieri B. Stem cells in clinical practice: applications and warnings. $J$ Exp Clin Cancer Res. 2011;30:9.

19. Sieburg HB, Cho RH, Dykstra B, Uchida N, Eaves CJ, Muller-Sieburg CE. The hematopoietic stem compartment consists of a limited number of discrete stem cell subsets. Blood. 2006;107(6):2311-2316.

20. Alev C, Ii M, Asahara T. Endothelial progenitor cells: a novel tool for the therapy of ischemic diseases. Antioxid Redox Signal. 2011;15(4):949-965.

21. Prater DN, Case J, Ingram DA, Yoder MC. Working hypothesis to redefine endothelial progenitor cells. Leukemia. 2007;21(6):1141-1149.

22. Peichev M, Naiyer AJ, Pereira D, et al. Expression of VEGFR-2 and AC133 by circulating human CD34(+) cells identifies a population of functional endothelial precursors. Blood. 2000;95(3):952-958.

23. Timmermans F, Van Hauwermeiren F, De Smedt M, et al. Endothelial outgrowth cells are not derived from CD133+ cells or CD45+ hematopoietic precursors. Arterioscler Thromb Vasc Biol. 2007;27(7):1572-1579.

24. Case J, Mead LE, Bessler WK, et al. Human CD34+AC133+VEGFR-2+ cells are not endothelial progenitor cells but distinct, primitive hematopoietic progenitors. Exp Hematol. 2007;35(7):1109-1118.

25. Mund JA, Case J. The role of circulating endothelial progenitor cells in tumor angiogenesis. Curr Stem Cell Res Ther. 2011;6(2):115-121.

26. Estes ML, Mund JA, Ingram DA, Case J. Identification of endothelial cells and progenitor cell subsets in human peripheral blood. Curr Protoc Cytom. 2010; Chapter 9:Unit 9.33.1-11.

27. Tongers J, Losordo DW, Landmesser U. Stem and progenitor cellbased therapy in ischaemic heart disease: promise, uncertainties, and challenges. Eur Heart J. 2011;32(10):1197-1206.

28. Bissels U, Wild S, Tomiuk S, et al. Combined characterization of microRNA and mRNA profiles delineates early differentiation pathways of CD133+ and CD34+ hematopoietic stem and progenitor cells. Stem Cells. 2011;29(5):847-857.

29. Copland IB. Mesenchymal stromal cells for cardiovascular disease. J Cardiovasc Dis Res. 2011;2(1):3-13.

30. Wagner J, Kean T, Young R, Dennis JE, Caplan AI. Optimizing mesenchymal stem cell-based therapeutics. Curr Opin Biotechnol. 2009;20(5):531-536.

31. Ripa RS, Haack-Sorensen M, Wang Y, et al. Bone marrow derived mesenchymal cell mobilization by granulocyte-colony stimulating factor after acute myocardial infarction: results from the Stem Cells in Myocardial Infarction (STEMMI) trial. Circulation. 2007;116(11 Suppl):I24-I30.

32. Kern S, Eichler H, Stoeve J, Kluter H, Bieback K. Comparative analysis of mesenchymal stem cells from bone marrow, umbilical cord blood, or adipose tissue. Stem Cells. 2006;24(5):1294-1301.

33. Wagner W, Wein F, Seckinger A, et al. Comparative characteristics of mesenchymal stem cells from human bone marrow, adipose tissue, and umbilical cord blood. Exp Hematol. 2005;33(11):1402-1416. 
34. Gaebel R, Furlani D, Sorg H, et al. Cell origin of human mesenchymal stem cells determines a different healing performance in cardiac regeneration. PLoS One. 2011;6(2):e15652.

35. Lee JS, Hong JM, Moon GJ, Lee PH, Ahn YH, Bang OY. A longterm follow-up study of intravenous autologous mesenchymal stem cell transplantation in patients with ischemic stroke. Stem Cells. 2010;28(6):1099-1106.

36. Chen SL, Fang WW, Ye F, et al. Effect on left ventricular function of intracoronary transplantation of autologous bone marrow mesenchymal stem cell in patients with acute myocardial infarction. Am J Cardiol. 2004;94(1):92-95.

37. Hare JM, Traverse JH, Henry TD, et al. A randomized, double-blind, placebo-controlled, dose-escalation study of intravenous adult human mesenchymal stem cells (prochymal) after acute myocardial infarction. J Am Coll Cardiol. 2009;54(24):2277-2286.

38. Trounson A, Thakar RG, Lomax G, Gibbons D. Clinical trials for stem cell therapies. BMC Med. 2011;9:52.

39. Carvalho AB, de Carvalho AC. Heart regeneration: past, present and future. World J Cardiol. 2010;2(5):107-111.

40. Martin CM, Meeson AP, Robertson SM, et al. Persistent expression of the ATP-binding cassette transporter, Abcg2, identifies cardiac SP cells in the developing and adult heart. Dev Biol. 2004;265(1):262-275.

41. Oh H, Bradfute SB, Gallardo TD, et al. Cardiac progenitor cells from adult myocardium: homing, differentiation, and fusion after infarction. Proc Natl Acad Sci U S A. 2003;100(21):12313-12318.

42. Matsuura K, Nagai T, Nishigaki N, et al. Adult cardiac Sca-1positive cells differentiate into beating cardiomyocytes. $J$ Biol Chem. 2004;279(12):11384-11391.

43. Messina E, De Angelis L, Frati G, et al. Isolation and expansion of adult cardiac stem cells from human and murine heart. Circ Res. 2004;95(9):911-921.

44. Laugwitz KL, Moretti A, Lam J, et al. Postnatal isl1+ cardioblasts enter fully differentiated cardiomyocyte lineages. Nature. 2005;433(7026):647-653.

45. Beltrami AP, Barlucchi L, Torella D, et al. Adult cardiac stem cells are multipotent and support myocardial regeneration. Cell. 2003;114(6): 763-776.

46. Davis DR, Kizana E, Terrovitis J, et al. Isolation and expansion of functionally-competent cardiac progenitor cells directly from heart biopsies. J Mol Cell Cardiol. 2010;49(2):312-321.

47. Davis DR, Ruckdeschel Smith R, Marban E. Human cardiospheres are a source of stem cells with cardiomyogenic potential. Stem Cells. 2010;28(5):903-904.

48. Zhang Y, Li TS, Lee ST, et al. Dedifferentiation and proliferation of mammalian cardiomyocytes. PLoS One. 2010;5(9):e12559.

49. Yamada Y, Yokoyama S, Wang XD, Fukuda N, Takakura N. Cardiac stem cells in brown adipose tissue express CD133 and induce bone marrow nonhematopoietic cells to differentiate into cardiomyocytes. Stem Cells. 2007;25(5):1326-1333.

50. Yamada Y, Wang XD, Yokoyama S, Fukuda N, Takakura N. Cardiac progenitor cells in brown adipose tissue repaired damaged myocardium. Biochem Biophys Res Commun. 2006;342(2):662-670.

51. Bolli R, Chugh AR, D'Amario D, et al. Cardiac stem cells in patients with ischaemic cardiomyopathy (SCIPIO): initial results of a randomised Phase 1 trial. Lancet. 2011;378(9806):1847-1857.

52. Madonna R, Geng YJ, De Caterina R. Adipose tissue-derived stem cells: characterization and potential for cardiovascular repair. Arterioscler Thromb Vasc Biol. 2009;29(11):1723-1729.

53. Madonna R, De Caterina R. Adipose tissue: a new source for cardiovascular repair. J Cardiovasc Med. 2010;11(2):71-80.

54. Bai X, Yan Y, Song YH, et al. Both cultured and freshly isolated adipose tissue-derived stem cells enhance cardiac function after acute myocardial infarction. Eur Heart J. 2010;31(4):489-501.

55. Takahashi M, Suzuki E, Oba S, et al. Adipose tissue-derived stem cells inhibit neointimal formation in a paracrine fashion in rat femoral artery. Am J Physiol Heart Circ Physiol. 2010;298(2):H415-H423.
56. Martinez-Fernandez A, Nelson TJ, Terzic A. Nuclear reprogramming strategy modulates differentiation potential of induced pluripotent stem cells. J Cardiovasc Transl Res. 2011;4(2):131-137.

57. Thomson JA, Itskovitz-Eldor J, Shapiro SS, et al. Embryonic stem cell lines derived from human blastocysts. Science. 1998;282(5391):1145-1147.

58. Braam SR, Denning C, Mummery CL. Genetic manipulation of human embryonic stem cells in serum and feeder-free media. Methods Mol Biol. 2010;584:413-423.

59. Bhatia M, Bonnet D, Kapp U, Wang JC, Murdoch B, Dick JE. Quantitative analysis reveals expansion of human hematopoietic repopulating cells after short-term ex vivo culture. J Exp Med. 1997;186(4):619-624.

60. Varnum-Finney B, Xu L, Brashem-Stein C, et al. Pluripotent, cytokinedependent, hematopoietic stem cells are immortalized by constitutive Notch1 signaling. Nat Med. 2000;6(11):1278-1281.

61. Kelly SS, Sola CB, de Lima M, Shpall E. Ex vivo expansion of cord blood. Bone Marrow Transplant. 2009;44(10):673-681.

62. Boitano AE, Wang J, Romeo R, et al. Aryl hydrocarbon receptor antagonists promote the expansion of human hematopoietic stem cells. Science. 2010;329(5997):1345-1348.

63. Peled T, Mandel J, Goudsmid RN, et al. Pre-clinical development of cord blood-derived progenitor cell graft expanded ex vivo with cytokines and the polyamine copper chelator tetraethylenepentamine. Cytotherapy. 2004;6(4):344-355.

64. Zhang CC, Kaba M, Iizuka S, Huynh H, Lodish HF. Angiopoietinlike 5 and IGFBP2 stimulate ex vivo expansion of human cord blood hematopoietic stem cells as assayed by NOD/SCID transplantation. Blood. 2008;111(7):3415-3423.

65. Reya T, Duncan AW, Ailles L, et al. A role for Wnt signalling in self-renewal of haematopoietic stem cells. Nature. 2003;423(6938): 409-414.

66. Murdoch B, Chadwick K, Martin M, et al. Wnt-5A augments repopulating capacity and primitive hematopoietic development of human blood stem cells in vivo. Proc Natl Acad Sci U S A. 2003; 100(6): 3422-3427.

67. Perez-Simon JA, Lopez-Villar O, Andreu EJ, et al. Mesenchymal stem cells expanded in vitro with human serum for the treatment of acute and chronic graft-versus-host disease: results of a Phase I/II clinical trial. Haematologica. 2011;96(7):1072-1076.

68. Lu J, Aggarwal R, Pompili VJ, Das H. A novel technology for hematopoietic stem cell expansion using combination of nanofiber and growth factors. Recent Pat Nanotechnol. 2010;4(2):125-135.

69. Walenda T, Bokermann G, Ventura Ferreira MS, et al. Synergistic effects of growth factors and mesenchymal stromal cells for expansion of hematopoietic stem and progenitor cells. Exp Hematol. 2011;39(6): 617-628.

70. Dahlberg A, Delaney C, Bernstein ID. Ex vivo expansion of human hematopoietic stem and progenitor cells. Blood. 2011;117(23): 6083-6090.

71. Delaney C, Ratajczak MZ, Laughlin MJ. Strategies to enhance umbilical cord blood stem cell engraftment in adult patients. Expert Rev Hematol. 2010;3(3):273-283.

72. Madonna R, De Caterina R. Stem cells and growth factor delivery systems for cardiovascular disease. J Biotechnology. 2011;154(4):291-297.

73. Krankel N, Spinetti G, Amadesi S, Madeddu P. Targeting stem cell niches and trafficking for cardiovascular therapy. Pharmacol Ther. 2011;129(1):62-81.

74. Voog J, Jones DL. Stem cells and the niche: a dynamic duo. Cell Stem Cell. 2010;6(2):103-115.

75. Martinez EC, Kofidis T. Adult stem cells for cardiac tissue engineering. J Mol Cell Cardiol. 2011;50(2):312-319.

76. Bollini S, Smart N, Riley PR. Resident cardiac progenitor cells: at the heart of regeneration. J Mol Cell Cardiol. 2011;50(2):296-303.

77. Morrison SJ, Spradling AC. Stem cells and niches: mechanisms that promote stem cell maintenance throughout life. Cell. 2008;132(4):598-611. 
78. Tamura Y, Matsumura K, Sano M, et al. Neural crest-derived stem cells migrate and differentiate into cardiomyocytes after myocardial infarction. Arterioscler Thromb Vasc Biol. 2011;31(3):582-589.

79. Barker N, Clevers H. Tracking down the stem cells of the intestine: strategies to identify adult stem cells. Gastroenterology. 2007;133(6): 1755-1760.

80. Nervi B, Link DC, DiPersio JF. Cytokines and hematopoietic stem cell mobilization. J Cell Biochem. 2006;99(3):690-705.

81. Heissig B, Hattori K, Dias S, et al. Recruitment of stem and progenitor cells from the bone marrow niche requires MMP-9 mediated release of kit-ligand. Cell. 2002;109(5):625-637.

82. Heissig B, Lund LR, Akiyama H, et al. The plasminogen fibrinolytic pathway is required for hematopoietic regeneration. Cell Stem Cell. 2007;1(6):658-670.

83. Levesque JP, Liu F, Simmons PJ, et al. Characterization of hematopoietic progenitor mobilization in protease-deficient mice. Blood. 2004; 104(1):65-72.

84. Pelus LM, Bian H, King AG, Fukuda S. Neutrophil-derived MMP-9 mediates synergistic mobilization of hematopoietic stem and progenitor cells by the combination of G-CSF and the chemokines GRObeta/CXCL2 and GRObetaT/CXCL2delta4. Blood. 2004;103(1): 110-119.

85. Tjwa M, Moura R, Moons L, et al. Fibrinolysis-independent role of plasmin and its activators in the haematopoietic recovery after myeloablation. J Cell Mol Med. 2009;13(11-12):4587-4595.

86. Gong Y, Fan Y, Hoover-Plow J. Plasminogen regulates stromal cellderived factor-1/CXCR4-mediated hematopoietic stem cell mobilization by activation of matrix metalloproteinase-9. Arterioscler Thromb Vasc Biol. 2011;31(9):2035-2043.

87. Cramer DE, Wagner S, Li B, et al. Mobilization of hematopoietic progenitor cells by yeast-derived beta-glucan requires activation of matrix metalloproteinase-9. Stem Cells. 2008;26(5): 1231-1240.

88. Robinson SN, Pisarev VM, Chavez JM, Singh RK, Talmadge JE. Use of matrix metalloproteinase (MMP)-9 knockout mice demonstrates that MMP-9 activity is not absolutely required for G-CSF or Flt-3 ligandinduced hematopoietic progenitor cell mobilization or engraftment. Stem Cells. 2003;21(4):417-427.

89. Jin F, Zhai Q, Qiu L, et al. Degradation of BM SDF-1 by MMP-9: the role in G-CSF-induced hematopoietic stem/progenitor cell mobilization. Bone Marrow Transplant. 2008;42(9):581-588.

90. McQuibban GA, Butler GS, Gong JH, et al. Matrix metalloproteinase activity inactivates the $\mathrm{CXC}$ chemokine stromal cell-derived factor-1. J Biol Chem. 2001;276(47):43503-43508.

91. Stiff P, Gingrich R, Luger S, et al. A randomized Phase 2 study of PBPC mobilization by stem cell factor and filgrastim in heavily pretreated patients with Hodgkin's disease or non-Hodgkin's lymphoma. Bone Marrow Transplant. 2000;26(5):471-481.

92. Holm M. Not all healthy donors mobilize hematopoietic progenitor cells sufficiently after G-CSF administration to allow for subsequent CD34 purification of the leukapheresis product. $J$ Hematother. 1998;7(2):111-113.

93. Anderlini P, Przepiorka D, Seong C, et al. Factors affecting mobilization of CD34+ cells in normal donors treated with filgrastim. Transfusion. 1997;37(5):507-512

94. Devine SM, Flomenberg N, Vesole DH, et al. Rapid mobilization of CD34+ cells following administration of the CXCR4 antagonist AMD3100 to patients with multiple myeloma and non-Hodgkin's lymphoma. J Clin Oncol. 2004;22(6):1095-1102.

95. Hendrix CW, Flexner C, MacFarland RT, et al. Pharmacokinetics and safety of AMD-3100, a novel antagonist of the CXCR-4 chemokine receptor, in human volunteers. Antimicrob Agents Chemother. 2000;44(6): 1667-1673.

96. Liles WC, Broxmeyer HE, Rodger E, et al. Mobilization of hematopoietic progenitor cells in healthy volunteers by AMD3100, a CXCR4 antagonist. Blood. 2003;102(8):2728-2730.
97. Flomenberg N, Devine SM, Dipersio JF, et al. The use of AMD3100 plus G-CSF for autologous hematopoietic progenitor cell mobilization is superior to G-CSF alone. Blood. 2005;106(5): 1867-1874.

98. Lack NA, Green B, Dale DC, et al. A pharmacokineticpharmacodynamic model for the mobilization of CD34+ hematopoietic progenitor cells by AMD3100. Clin Pharmacol Ther. 2005;77(5): 427-436.

99. Dai S, Yuan F, Mu J, et al. Chronic AMD3100 antagonism of SDF1alpha-CXCR4 exacerbates cardiac dysfunction and remodeling after myocardial infarction. J Mol Cell Cardiol. 2010;49(4):587-597.

100. Liang SX, Tan TY, Gaudry L, Chong B. Differentiation and migration of Sca1+/CD31- cardiac side population cells in a murine myocardial ischemic model. Int J Cardiol. 2010;138(1):40-49.

101. Yamahara K, Fukushima S, Coppen SR, et al. Heterogeneic nature of adult cardiac side population cells. Biochem Biophys Res Commun. 2008;371(4):615-620.

102. Scherschel JA, Soonpaa MH, Srour EF, Field LJ, Rubart M. Adult bone marrow-derived cells do not acquire functional attributes of cardiomyocytes when transplanted into peri-infarct myocardium. Mol Ther. 2008;16(6):1129-1137.

103. Orlic D, Kajstura J, Chimenti S, et al. Bone marrow cells regenerate infarcted myocardium. Nature. 2001;410(6829):701-705.

104. Bearzi C, Rota M, Hosoda T, et al. Human cardiac stem cells. Proc Natl Acad Sci U S A. 2007;104(35):14068-14073.

105. Bocchi L, Savi M, Graiani G, et al. Growth factor-induced mobilization of cardiac progenitor cells reduces the risk of arrhythmias, in a rat model of chronic myocardial infarction. PLoS One. 2011; 6(3):e17750.

106. Vieira JM, Riley PR. Epicardium-derived cells: a new source of regenerative capacity. Heart. 2011;97(1):15-19.

107. Smart N, Bollini S, Dube $\mathrm{KN}$, et al. De novo cardiomyocytes from within the activated adult heart after injury. Nature. 2011;474(7353):640-644.

108. Ott HC, Matthiesen TS, Brechtken J, et al. The adult human heart as a source for stem cells: repair strategies with embryonic-like progenitor cells. Nat Clin Pract Cardiovasc Med. 2007;4 Suppl 1: S27-S39.

109. Tateishi K, Ashihara E, Takehara N, et al. Clonally amplified cardiac stem cells are regulated by Sca-1 signaling for efficient cardiovascular regeneration. J Cell Sci. 2007;120(Pt 10):1791-1800.

110. Chiriac A, Nelson TJ, Faustino RS, Behfar A, Terzic A. Cardiogenic induction of pluripotent stem cells streamlined through a conserved SDF-1/VEGF/BMP2 integrated network. PLoS One. 2010;5(4):e9943.

111. Dib N, Khawaja H, Varner S, McCarthy M, Campbell A. Cell therapy for cardiovascular disease: a comparison of methods of delivery. J Cardiovasc Transl Res. 2011;4(2):177-181.

112. Musialek P, Tekieli L, Kostkiewicz M, et al. Randomized transcoronary delivery of CD34(+) cells with perfusion versus stop-flow method in patients with recent myocardial infarction: early cardiac retention of (m)Tc-labeled cells activity. J Nucl Cardiol. 2011;18(1):104-116.

113. Guo HD, Cui GH, Wang HJ, Tan YZ. Transplantation of marrow-derived cardiac stem cells carried in designer self-assembling peptide nanofibers improves cardiac function after myocardial infarction. Biochem Biophys Res Commun. 2010;399(1):42-48.

114. Kai D, Prabhakaran MP, Jin G, Ramakrishna S. Guided orientation of cardiomyocytes on electrospun aligned nanofibers for cardiac tissue engineering. J Biomed Mater Res B Appl Biomater. 2011;98B(2):379-386.

115. Zakharova L, Mastroeni D, Mutlu N, et al. Transplantation of cardiac progenitor cell sheet onto infarcted heart promotes cardiogenesis and improves function. Cardiovasc Res. 2010;87(1):40-49.

116. Fukuda S, Bian H, King AG, Pelus LM. The chemokine GRObeta mobilizes early hematopoietic stem cells characterized by enhanced homing and engraftment. Blood. 2007;110(3):860-869. 
117. Hristov M, Zernecke A, Bidzhekov K, et al. Importance of CXC chemokine receptor 2 in the homing of human peripheral blood endothelial progenitor cells to sites of arterial injury. Circ Res. 2007;100(4):590-597.

118. Penn MS, Khalil MK. Exploitation of stem cell homing for gene delivery. Expert Opin Biol Ther. 2008;8(1):17-30.

119. Lapidot T, Dar A, Kollet O. How do stem cells find their way home? Blood. 2005;106(6):1901-1910.

120. Kurdi M, Booz GW. G-CSF-based stem cell therapy for the heartunresolved issues part A: paracrine actions, mobilization, and delivery. Congest Heart Fail. 2007;13(4):221-227.

121. Qian H, Tryggvason K, Jacobsen SE, Ekblom M. Contribution of alpha6 integrins to hematopoietic stem and progenitor cell homing to bone marrow and collaboration with alpha4 integrins. Blood. 2006;107(9):3503-3510.

122. Mayorga M, Finan A, Penn M. Pre-transplantation specification of stem cells to cardiac lineage for regeneration of cardiac tissue. Stem Cell Rev. 2009;5(1):51-60.

123. Askari AT, Unzek S, Popovic ZB, et al. Effect of stromal-cell-derived factor 1 on stem-cell homing and tissue regeneration in ischaemic cardiomyopathy. Lancet. 2003;362(9385):697-703.

124. Schenk S, Mal N, Finan A, et al. Monocyte chemotactic protein-3 is a myocardial mesenchymal stem cell homing factor. Stem Cells. 2007;25(1):245-251

125. Kempf T, Zarbock A, Widera C, et al. GDF-15 is an inhibitor of leukocyte integrin activation required for survival after myocardial infarction in mice. Nat Med. 2011;17(5):581-588.

126. Zhang M, Mal N, Kiedrowski M, et al. SDF-1 expression by mesenchymal stem cells results in trophic support of cardiac myocytes after myocardial infarction. FASEB J. 2007;21(12): 3197-3207.

127. Hiasa K, Egashira K, Kitamoto S, et al. Bone marrow mononuclear cell therapy limits myocardial infarct size through vascular endothelial growth factor. Basic Res Cardiol. 2004;99(3):165-172.

128. Segers VF, Tokunou T, Higgins LJ, MacGillivray C, Gannon J, Lee RT. Local delivery of protease-resistant stromal cell derived factor-1 for stem cell recruitment after myocardial infarction. Circulation. 2007;116(15):1683-1692.

129. Kahn J, Byk T, Jansson-Sjostrand L, et al. Overexpression of CXCR4 on human CD34+ progenitors increases their proliferation, migration, and NOD/SCID repopulation. Blood. 2004;103(8): 2942-2949.

130. Cheng Z, Ou L, Zhou X, et al. Targeted migration of mesenchymal stem cells modified with CXCR4 gene to infarcted myocardium improves cardiac performance. Mol Ther. 2008;16(3):571-579.

131. Zhang D, Fan GC, Zhou X, et al. Over-expression of CXCR4 on mesenchymal stem cells augments myoangiogenesis in the infarcted myocardium. J Mol Cell Cardiol. 2008;44(2):281-292.

132. Takehara N, Tsutsumi Y, Tateishi K, et al. Controlled delivery of basic fibroblast growth factor promotes human cardiosphere-derived cell engraftment to enhance cardiac repair for chronic myocardial infarction. J Am Coll Cardiol. 2008;52(23):1858-1865.

133. Ip JE, Wu Y, Huang J, Zhang L, Pratt RE, Dzau VJ. Mesenchymal stem cells use integrin beta 1 not $\mathrm{CXC}$ chemokine receptor 4 for myocardial migration and engraftment. Mol Biol Cell. 2007;18(8):2873-2882.

134. Borg TK, Markwald R. Periostin: more than just an adhesion molecule. Circ Res. 2007;101(3):230-231.

135. Xiang G, Schuster MD, Seki T, Witkowski P, Eshghi S, Itescu S. Downregulated expression of plasminogen activator inhibitor-1 augments myocardial neovascularization and reduces cardiomyocyte apoptosis after acute myocardial infarction. $\mathrm{J} \mathrm{Am} \mathrm{Coll} \mathrm{Cardiol.}$ 2005;46(3):536-541.

136. Shimazaki M, Nakamura K, Kii I, et al. Periostin is essential for cardiac healing after acute myocardial infarction. J Exp Med. 2008;205(2):295-303.
137. Byk T, Kahn J, Kollet O, et al. Cycling G1 CD34+/CD38+ cells potentiate the motility and engraftment of quiescent G0 CD34+/CD38-/low severe combined immunodeficiency repopulating cells. Stem Cells. 2005;23(4):561-574.

138. Janowska-Wieczorek A, Marquez LA, Dobrowsky A, Ratajczak MZ, Cabuhat ML. Differential MMP and TIMP production by human marrow and peripheral blood CD34(+) cells in response to chemokines. Exp Hematol. 2000;28(11):1274-1285.

139. Zheng Y, Sun A, Han ZC. Stem cell factor improves SCID-repopulating activity of human umbilical cord blood-derived hematopoietic stem/ progenitor cells in xenotransplanted NOD/SCID mouse model. Bone Marrow Transplant. 2005;35(2):137-142.

140. Petit I, Szyper-Kravitz M, Nagler A, et al. G-CSF induces stem cell mobilization by decreasing bone marrow SDF-1 and up-regulating CXCR4. Nature Immunology. 2002;3(7):687-694.

141. Levesque JP, Hendy J, Takamatsu Y, Simmons PJ, Bendall LJ. Disruption of the CXCR4/CXCL12 chemotactic interaction during hematopoietic stem cell mobilization induced by GCSF or cyclophosphamide. J Clin Invest. 2003;111(2):187-196.

142. Delgado MB, Clark-Lewis I, Loetscher P, et al. Rapid inactivation of stromal cell-derived factor-1 by cathepsin $\mathrm{G}$ associated with lymphocytes. Eur J Immunol. 2001;31(3):699-707.

143. Papayannopoulou T, Craddock C, Nakamoto B, Priestley GV, Wolf NS. The VLA4/VCAM-1 adhesion pathway defines contrasting mechanisms of lodgement of transplanted murine hemopoietic progenitors between bone marrow and spleen. Proc Natl Acad Sci USA. 1995;92(21):9647-9651.

144. Papayannopoulou T, Priestley GV, Nakamoto B, Zafiropoulos V, Scott LM, Harlan JM. Synergistic mobilization of hemopoietic progenitor cells using concurrent beta1 and beta 2 integrin blockade or beta2-deficient mice. Blood. 2001;97(5):1282-1288.

145. Bonig H, Priestley GV, Papayannopoulou T. Hierarchy of molecularpathway usage in bone marrow homing and its shift by cytokines. Blood. 2006;107(1):79-86.

146. Wu Y, Ip JE, Huang J, et al. Essential role of ICAM-1/CD18 in mediating EPC recruitment, angiogenesis, and repair to the infarcted myocardium. Circ Res. 2006;99(3):315-322.

147. Gu X, Xie Y, Gu J, et al. Repeated intracoronary infusion of peripheral blood stem cells with G-CSF in patients with refractory ischemic heart failure - a pilot study. Circ J. 2011;75(4):955-963.

148. Lasala GP, Silva JA, Kusnick BA, Minguell JJ. Combination stem cell therapy for the treatment of medically refractory coronary ischemia: a Phase I study. Cardiovasc Revasc Med. 2011;12(1): 29-34.

149. Surder D, Schwitter J, Moccetti T, et al. Cell-based therapy for myocardial repair in patients with acute myocardial infarction: rationale and study design of the SWiss multicenter Intracoronary Stem cells Study in Acute Myocardial Infarction (SWISS-AMI). Am Heart $J$. 2010;160(1):58-64.

150. Yao Y, Li Y, Ma G, et al. In vivo magnetic resonance imaging of injected endothelial progenitor cells after myocardial infarction in rats. Mol Imaging Biol. 2011;13(2):303-313.

151. Ebert SN, Taylor DG, Nguyen HL, et al. Noninvasive tracking of cardiac embryonic stem cells in vivo using magnetic resonance imaging techniques. Stem Cells. 2007;25(11):2936-2944.

152. Zhou R, Idiyatullin D, Moeller S, et al. SWIFT detection of SPIOlabeled stem cells grafted in the myocardium. Magn Reson Med. 2010;63(5):1154-1161.

153. Tang J, Wang J, Kong X, et al. Vascular endothelial growth factor promotes cardiac stem cell migration via the PI3 K/Akt pathway. Exp Cell Res. 2009;315(20):3521-3531.

154. Higuchi T, Anton M, Saraste A, et al. Reporter gene PET for monitoring survival of transplanted endothelial progenitor cells in the rat heart after pretreatment with VEGF and atorvastatin. $J$ Nucl Med. 2009;50(11):1881-1886. 
155. Adler ED, Bystrup A, Briley-Saebo KC, et al. In vivo detection of embryonic stem cell-derived cardiovascular progenitor cells using Cy3-labeled Gadofluorine M in murine myocardium. JACC Cardiovasc Imaging. 2009;2(9):1114-1122.

156. Hsieh PC, Segers VF, Davis ME, et al. Evidence from a genetic fate-mapping study that stem cells refresh adult mammalian cardiomyocytes after injury. Nat Med. 2007;13(8):970-974.
157. Synnergren J, Akesson K, Dahlenborg K, et al. Molecular signature of cardiomyocyte clusters derived from human embryonic stem cells. Stem Cells. 2008;26(7):1831-1840.

158. Ma Q, Zhou B, Pu WT. Reassessment of Isl1 and Nkx2-5 cardiac fate maps using a Gata4-based reporter of Cre activity. Dev Biol. 2008;323(1):98-104.

\section{Publish your work in this journal}

Vascular Health and Risk Management is an international, peerreviewed journal of therapeutics and risk management, focusing on concise rapid reporting of clinical studies on the processes involved in the maintenance of vascular health; the monitoring, prevention and treatment of vascular disease and its sequelae; and the involvement of metabolic disorders, particularly diabetes. This journal is indexed on PubMed Central and MedLine. The manuscript management system is completely online and includes a very quick and fair peer-review system, which is all easy to use. Visit http://www.dovepress.com/ testimonials.php to read real quotes from published authors.

Submit your manuscript here: http://www.dovepress.com/vascular-health-and-risk-management-journal 